\title{
PEMBERDAYAAN MANAJEMEN REMAJA MASJID DALAM MENINGKATKAN EKONOMI MELALUI HADRAH BANJARI DI DESA PONTEH KECAMATAN GALIS KABUPATEN PAMEKASAN
}

\author{
Mohammad Fahrur Rozi ${ }^{*}$ \\ Suhaimi ${ }^{2}$ \\ ${ }^{1}$ Fakultas Ilmu Administrasi Universitas Madura, Pamekaasan, Indonesia \\ ${ }^{2}$ Fakultas Hukum Universitas Madura, Pamekasan, Indonesia \\ mohammad.fahrur.rozi@unira.ac.id ${ }^{*}$ ) \\ suhaimi.dorez@gmail.com ${ }^{2}$
}

Kata Kunci: [Manajemen, Remaja Masjid, Hadrah Banjari]

Published by:

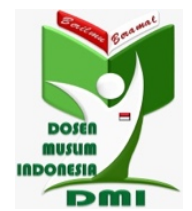

Copyright (C) 2022 The Author(s)

This article is licensed under CC BY 4.0 License

\begin{abstract}
Abstrak: Masjid merupakan tempat ibadah bagi umat muslim, oleh sebab itu masjid menjadi tempat yang paling mulia di muka bumi. Umat Islam wajib memakmurkan masjid baik dengan aktivitas keagamaan dan perayaan hari besar Islam. Dalam memakmurkan masjid membutuhkan biaya oprasional demi suksesnya acara. Faktanya, masjid tidak ada dana masukan dana yang pasti, hanya kotak amal jum'at dan sumbangan para dermawan yang dijadikan dana operasional. Oleh karena itu, pengabdian ini diadakan untuk meningkatkan ekonomi masjid melalui hadrah banjari. Hadrah banjari merupakan seni dan sudah menjadi tradisi di masyarakat Madura. Hal ini dibuktikan pada setiap acara pesta perkawinan, timangan bayi umur 40 hari (molangareh) selalu mengundang hadrah banjari. Dengan adanya pengabdian ini, diharapkan remaja masjid mempunyai semangat untuk membentuk group hadrah banjari untuk meningkatkan ekonomi masjid.
\end{abstract} $(\mathrm{cc}) \mathrm{EY}$ 


\section{Pendahuluan}

Manajemen merupakan proses yang harus dilakukan oleh setiap organisasi berupa tindakan atau perilaku untuk mencapai sasaran dan tujuan yang telah ditentukan dengan memanfaatkan sumber daya yang dimilikinya (Tunggal, 2002). Manajemen merupakan science yang dapat digunakan dalam berbagai aspek tidak lupa dapat digunakan untuk meningkatkan masjid. Masjid merupakan tempat yang paling mulia di muka bumi ini. Oleh karena itu, selaku umat Islam harus dapat memakmurkan masjid baik dalam shalatberjama'ah, mengaji, musyawarah atau bahkan dalam pendidikan dan pembinaan lainnya. Oleh karena itu dalam surat At Taubah: 18, artinya: "Hanyalah yang memakmurkan Masjid-Masjid Allah ialah orang-orang yang beriman kepada Allah dan hari kemudian, serta tetap mendirikan shalat, menunaikan zakat dan tidak takut (kepada siapapun) selain kepada Allah, maka merekalah orang-orang yang diharapkan termasuk golongan orang-orang yang mendapat petunjuk".

Melihat kembali yang pernah dilakukan oleh rasulullahsaw sebagai suri teladan umat Islam, masjid merupakan pusat aktivitas umat Islam, kaderisasi para sahabat, memelihara, dan mewarisi ajaran-ajaran agama dan peradaban Islam yang bermula dari masjid (Al-Mubarakfuri, 2008). Lebih dari itu, berbagai kegiatan maupun problematika umat yang menyangkut bidang agama, ilmu pengetahuan, politik, ekonomi dan sosial budaya semuanya dibahas di masjid. Masjid juga merupakan pranata keagamaan yang tak terpisahkan dari kehidupan spritual, sosial, dan kultural umat Islam. Keberadaan masjid dapat dipandang sebagai salah satu perwujudan dari eksistensi dan aspirasi umat Islam, khususnya sebagai sarana peribadatan yang menduduki fungsi sentral dalam kehidupan bermasyarakat. Sehingga pada masa itu masjid mampu menjadi pusat pengembangan kebudayaan Islam, sarana diskusi kritis, mengaji, serta memperdalam ilmu-ilmu pengetahuan agama secara khusus, dan pengetahuan umum secara luas. Hal ini sesuai dengan arah dan tujuan Pembangunan Nasional yaitu adalah pembangunan manusia Indonesia seutuhnya dan pembangunan seluruh masyarakat Indonesia (Siswanto, 2005).

Sementara kebanyakan masyarakat beranggapan dan melakukan, masjid sebagai tempat shalat dan mengaji (tadarrus), kegiatan keagamaan seperti isra'-mi'raj dan maulid Nabi Muhammad saw. Dalam memakmurkan masjid materi juga dibutuhkan seperti listrik, Air PDAM, biaya renovasi atau perbaikan alat masjid yang lumayan besar. Sementara ini, biaya operasional masjid hanya diperoleh dari uang amal masjid setiap hari jum'at (kotak amal pada pelaksanaan sholatjum'at) yang kadangkala tidak cukup untuk membayar listrik dan air.

Hadrah banjari adalah seni budaya keislaman yang kerap kali diundang oleh masyarakat dalam pesta pernikahan, perayaan maulid Nabi Muhammad saw dan timangan bayi 40 hari setelah kelahiran dan dalam konteks madura dikenal dengan sebut maelangareh (Mudjahidin, 1985). Jika masjid mempunyai hadrah banjari sedikit banyak sudah dapat menambah finansial untuk memakmurkan masjid baik dalam aspek bangunan maupun spiritual dengan kegiatan keagamaan. Inilah yang kemudian oleh pengabdi menjadi salah satu faktor perlu diadakannya pengabdian.

Hadrah banjari pada nantinya akan memberikan dampak bagi remaja masjid yang tidak hanya membersihkan masjid setiap jum'at, menjadi panitia keagamaan melainkan dengan hadrah banjari dapat membentuk karakter remaja masjid penuh tanggung jawab, meningkatkan cinta pada nabi muhammadsaw melalui sholawat dan tabuhan rebana. Tujuan pengabdian adalah memberikan kesadaran remaja masjid bahwa membentuk 
kelompok hadrah banjari dapat meningkatkan ekonomi masjid dan yang lebih penting mendapatkan pahala sehingga kelak mendapatkan syafa'at dari baginda Nabi Muhammad saw. Oleh karena itu pengabdi ingin memberikan pengabdian berupa "Pemberdayaan Manajemen Remaja Masjid dalam Meningkatkan Ekonomi Melalui Hadrah Banjari di Desa Ponteh Kecamatan Galis Kabupaten Pamekasan".

\section{Metode Pelaksanaan}

Pelaksanaan pengabdian kepada masyarakat dengan tema Pemberdayaan Manajemen Remaja Masjid dalam Meningkatkan Ekonomi Melalui Hadrah Banjari di laksanakan di Desa Ponteh Kecamatan Galis Kabupaten Pamekasan dengan bermitrakan Remaja Masjid Rabi'atul Adhawiyah dan Remaja Masjid Al-Falah. Kedua remas ini secara keseluruhan berjumlah 35 orang. Tempat untuk melakukan pengadian dilaksanakan di Masjid Rabo'atulAhawiyah karena masjid ini berada di tengah-tengah Desa Ponteh dan padat penduduknya.

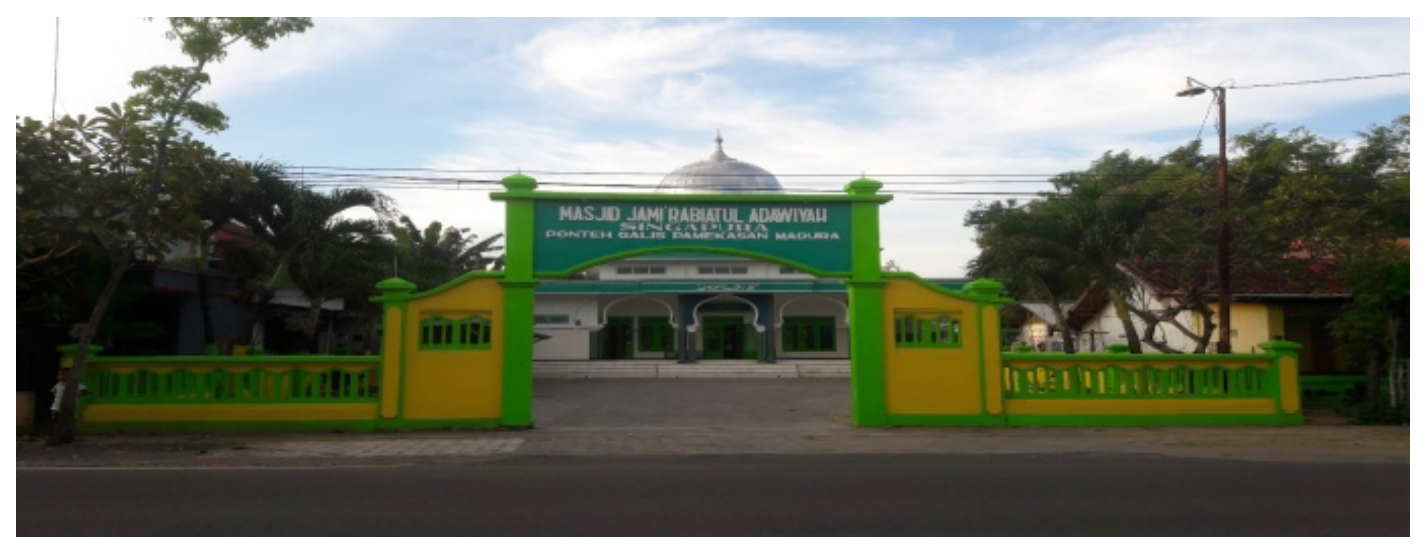

Gambar 1. Masjid Al-Falah Dusun Karang Panasan Desa Ponteh

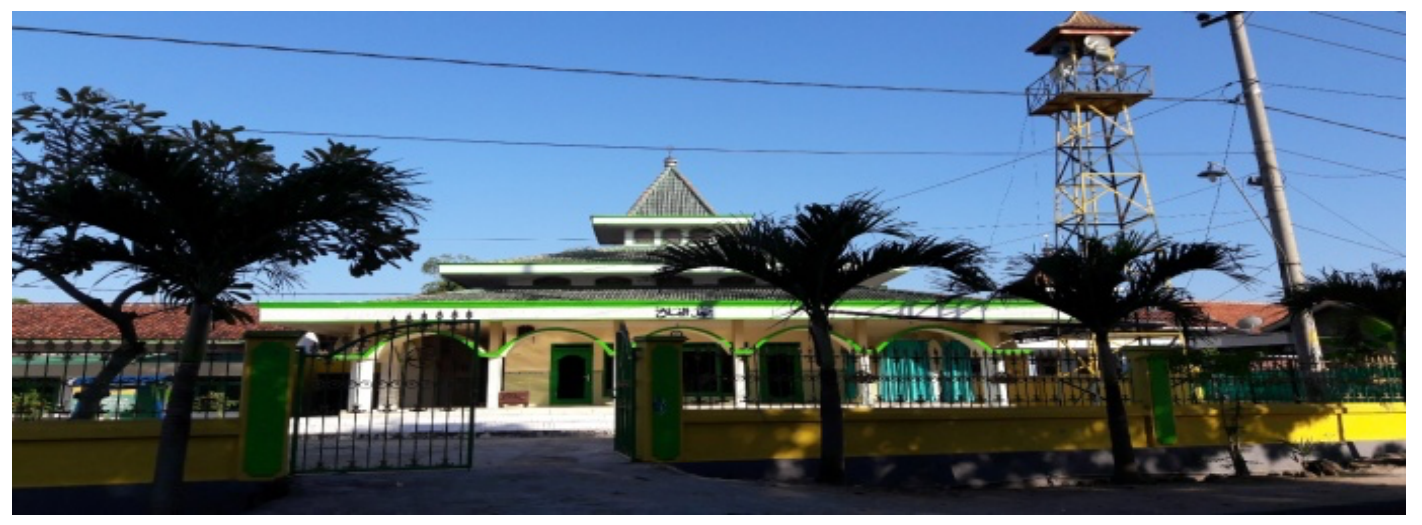

Gambar 2. Masjid Rabi’atul Adhawiyah Dusun Pandiyan Desa Ponteh

Metode yang digunakan dalam pengabdian kepada masyarakat ini menggunakan beberapa metode yaitu:

Ceramah. Metode ceramah ini digunakan untuk menyampaikan materi yang perlu disampaikan kepada mitra agar mitra memahami adanya pengabdian ini. Materi yang akan disampaikan sesuai dengan tema pengabdian yaitu kajian tentang manajemen, ekonomi dan hadrah banjari. Ketiga materi ini akan disampaikan oleh para ahlinya sesuai dengan bidangnya (Arif, 2002). 
1. Tanya Jawab. Sesi tanya jawab bertujuan untuk menanyakan suatu permasalahan yang tidak dipahami oleh mitra kepada narasumber, sehingga mitra benar-benar memahami dengan apa yang telah dijelaskan oleh mitra.

2. Pelatihan dan Pendampingan, mitra pada nantinya akan diajari bagaiana memegang dan manabuh rebana sehingga pada nantinya mitra tertarik untuk mengikuti pelatihan secara maksimal (pelatihan selanjutnya) jika biaya alat dan honor pelatih hadrah dapat dipenuhi dan disetujui oleh masingmasing masjid yang ada di Desa Ponteh Kecamatan Galis Kabupaten Pamekasan.

Dengan kedua metode ini, diharapkan mitra pengabdian mempunyai semangat untuk membentuk kelompok hadrah banjari oleh masing-masing masjid sebagai bentuk untuk meningkatkan ekonomi masjid dalam membangun dan mensejahterakan masjid yang lebih baik dan maju.

\section{Hasil dan Pembahasan}

\section{Pra-Pelaksanaan Kegiatan Pengabdian}

Sebelum melaksanakan kegiatan pengabdian masyarakat, maka tim pengabdian perlu melakukan persiapan sebagai berikut:

a. Tim pengabdian menentukan atau survey lokasi pengabdian

b. Tim Pengabdian mendapatkan Surat Tugas atau rekomendasi dari LPPM Universitas Madura.

c. Tim Pengabdian melakukan rapat untuk membagi tugas dan menyusun program kegiatan pengabdian.

d. Tim pengabdian menyusun rencana kerja pengabdian. Dalam hal ini mempersiapkan materi dalam powerpoint yang akan disampaikan dalam materi pengabdian. Tim Pelaksanaan kegiatan pengabdian ini dikemas dalam bentuk seminar pelatihan dan pendampingan dan menghasilkan beberapa kegaiatan yang dijelaskan dalam Tabel 3 berikut ini:

Tabel 3. Rencana Kerja Kegiatan Pengabdian Masyarakat Pemberdayaan Manajemen Remaja Masjid dalam Meningkatkan Ekonomi Melalui Hadrah Banjari di Desa Ponteh Kecamatan Galis Kabupaten Pamekasan.

\begin{tabular}{|c|c|c|c|}
\hline No & Nama Kegiatan & Waktu & Nara Sumber \\
\hline 1 & Pembukaan Oleh: & & \\
\hline & $\begin{array}{l}\text { a. Sambutan Tim Pengabdian } \\
\text { b. Sambutan Kepala Desa sebagai } \\
\text { perwakilan dari } 3 \text { Masjid Desa } \\
\text { Ponteh }\end{array}$ & 08.00 & $\begin{array}{l}\text { Mohammad Fahrur Rozi } \\
\text { Ibu Kepala Desa Ponteh }\end{array}$ \\
\hline 2 & Materi tentang Manajemen & 09.00 & Sukma Umbara Tirta Firdaus \\
\hline 3 & Materi tentang Ekonomi & 10.00 & Akhmad Farid Mawardi Sufyan \\
\hline 4 & Materi tentang Hadrah Banjari & 11.00 & Sakir \\
\hline 5 & Pertunjukan Hadrah Banjari & 12.00 & $\begin{array}{l}\text { Buq'atusSabibah Pondok } \\
\text { Pesantren Miftahul } \\
\text { QulubPolagan }\end{array}$ \\
\hline 6 & $\begin{array}{l}\text { Pelatihan dan } \\
\text { Hadrah Banjari }\end{array}$ & 12.30 & Sakir \\
\hline 7 & Do'a & - & Tokoh Agama \\
\hline
\end{tabular}


e. Sosialisasi. Pertama, Tim Pengabdian melakukan sosialisasi (silaturrahmi) ke 3 ta'mir masjid yang ada di Desa Ponteh dengan menyampaikan permasalahan, pelaksanaan kegiatan, serta tujuan kegiatan. Kedua, Tim Pengabdi menyampaikan surat pemberitahuan kepada Kepala Desa untuk akan melaksanakan pengabdian sekaligus membuka acara Pengabdian Kepada Masyarkat.

f. Tim Pengabdian menghubungi narasumber tentang Manajemen Remaja Masjid, Ekonomi dan Pembina Hadrah BanjariBuq'atusSabibah Pondok Pesantren Miftahul QulubPolagan. Pra-pelaksanaan perlu diadakan agar pada nantinya pelaksanaan pengabdian berjalan sesuai dengan program kegiatan dan tujuan diadakannya Pengabdian Kepada Masyarakat.

\section{Pelaksanaan Kegiatan Pengabdian}

Pengabdian ini dilaksanakan pada Tanggal 2 Desember 2021 di Masjid Rabi'atul Adhawiyah dengan rincian kegiatan sebagai berikut.

a. Pembukaan. Pembukaan berisi kata sambutan dari ketua tim pengabdian yang berisi permasalahan dan tujuan diadakannya pengabdian kepada masyarakat sebagai bentuk Tri Dharama Perguruan Tinggi Dosen Universitas Madura. Kepala Desa Ponteh sebagai tuan rumah dari mitra juga memberikan sambutan atas pengabdian yang akan dilaksanakan.

b. Pembahasan. Kegiatan pembahasan ini sudah dibentuk dan dibagi sesuai dengan narasumber masing-masing seperti:

1) Materi tentang manajemen remaja masjid. Materi ini bertujuan agar remaja masjid memahami pelaksanaan kegiatan manajemen pengelolaan masjid dalam meningkatkan wawasan pengetahuannya tentang pengelolaan masjid yang baik dan berkualitas. Rancangan kegiatan yang dilakukan yaitu kegiatan pelatihan pengelolaan manajemen mesjid dan remaja mesjid. Adapun materi pelatihan meliputi: pertama, materi tentang memakmurkan masjid. Kedua, materi tentang poblematika masjid dan remaja masjid. Ketiga, materi tentang manajemen pengelolaan masjid dan remaja masjid.

2) Materi tentang ekonomi. Materi ini bertujuan, remaja masjid dapat mengelola manajemen keuangan dengan baik dan benar dalam memakmurkan masjid mulai dana yang didapatkan, biaya pengeluaran tiap bulan, biaya tidak terduga dan biaya renovasi. Karena selama ini, dana operasional masjid kebanyakan berasal dari kotak amal jum'at. Oleh karena itu dalam materi ini akan dibahas bagaimana mendapatkan dana selain dari kotak amal jum'at.

3) Materi tentang hadrah banjari. Pada pembahasan ini, narasumber akan membahas sejarah hadrah banjari, alat-alat, bagaimana mempromosikan hadrah banjari serta pendapatan yang bisa didapatkan dari hadrah banjari ketika diundang oleh tuan rumah dalam acara pesta pernikahan, maulid Nabi Muhammad saw, timangan bayi 40 hari (maelangareh/melangareh) atau hajat tuan rumah yang lainnya. Pertunjukan Hadrah Banjari. Kegiatan ini sebagai hiburan dan pengenalan kepada remaja masjid Ponteh agar mitra tertarik untuk membuar kelompok hadrah banjari serta bagaimana penggunaan alatnya. Pelatihan ini dilakukan oleh anggota remaja masjid yang hadir. Mitra akan diajari bagaimana cara memegang dan menabuh rebana, tung tam, darbuka serta alat pendukung lainnya. 


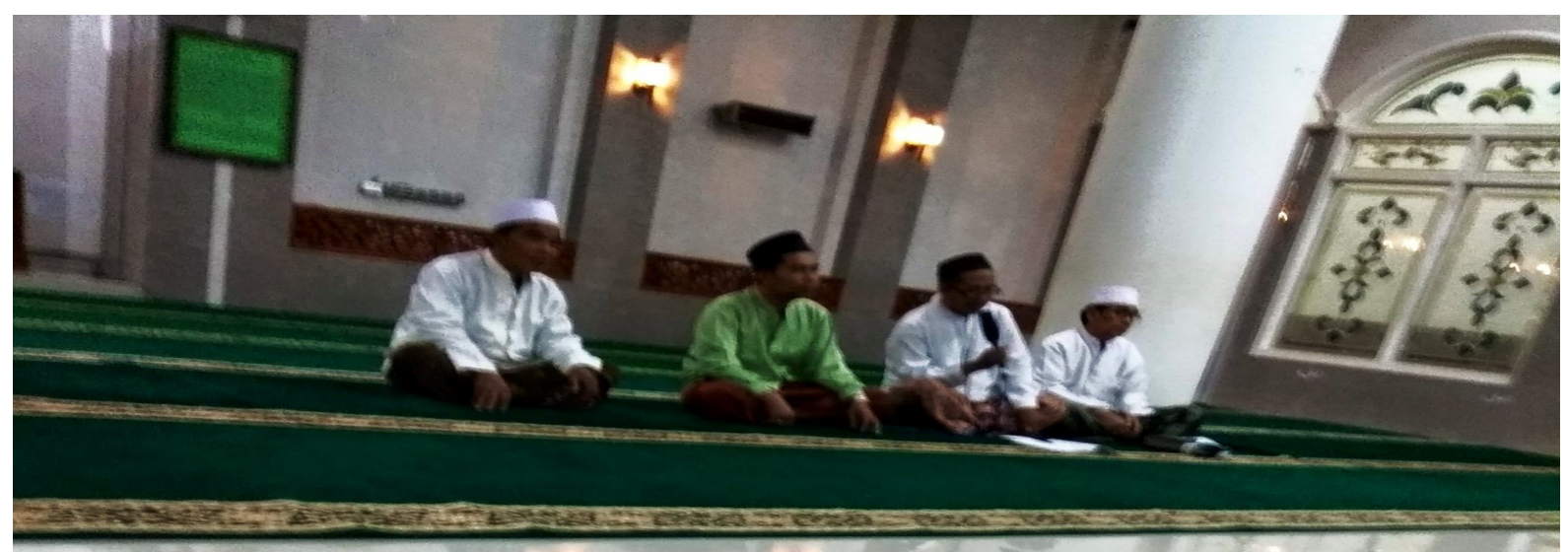

Gambar 3. Pelaksanaan Penbadian Kepada Masyarakat oleh Narasumber

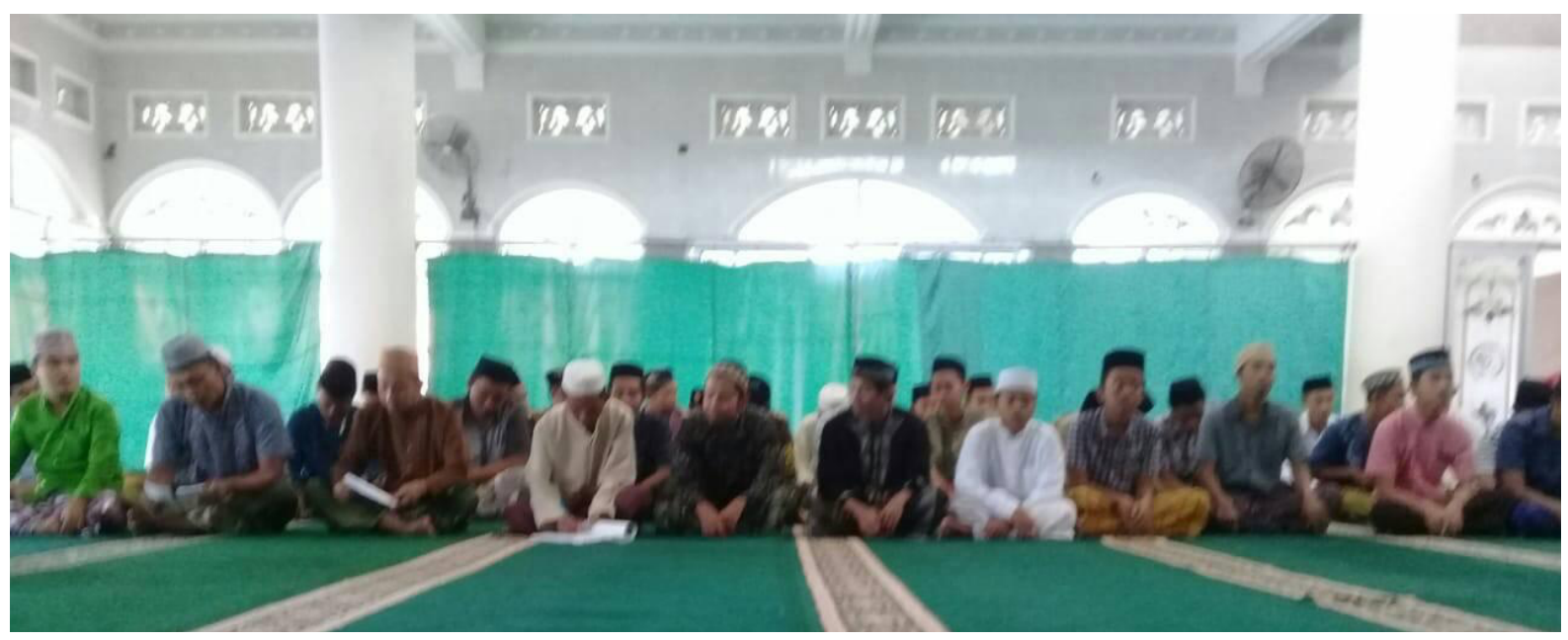

Gambar 4. Mitra Pengabdian Remaja Masjid

Semua pelaksanaan kegiatan ini disampaikan dengan teknik indoktrinasi dan teknik klarifikasi (Rozi, 2017 periksa juga di Madjid, 2000). Teknik indoktrinasi ini melalui beberapa tahapan yaitu: tahap pertama, brainwashing. Pada tahap ini para narasumber memulai merusak pemahaman mitra yang salah seperti manajemen masjid sulit, ribet, melelahkan, maulid nabi itu bid'ah, hadrah juga bid'ah dan pemahaman salah lainnya. Setelah mitra memahaminya maka narasumber akan memberikan pemahaman yang benar bahwa manajemen itu tidak sulit bahkan menyenangkan. Perayaan maulid Nabi Muhammad saw merupakan salah satu bentuk wujud kecintaan ummatnya kepada Nabi Muhammad saw yang didasarkan kepada hadist nabi dan al-Qur'an. Hadrah banjari merupakan seni budaya harus dijaga kelestariannya, karena menjaga seni budaya merupakan salah satu tugas generasi bangsa. Teknik klarifikasi terdiri dari beberapa tahapan salah satunya adalah pemberian contoh. Pada tahap ini pelatih hadrah banjari memberikan contoh bagaimana menabuh rebana, tung tam, darbuka sehingga menghasilkan nada dan ritme yang syahdu. Pada tahap ini, narasumber atau pelatih akan memberikan kesempatan kepada mitra untuk mencoba dan memainkan alat yang mereka sukai. Berangkat dari menyukai alat mereka pada nantinya aka tertarik dan ikut kelompok hadrah banjari. 


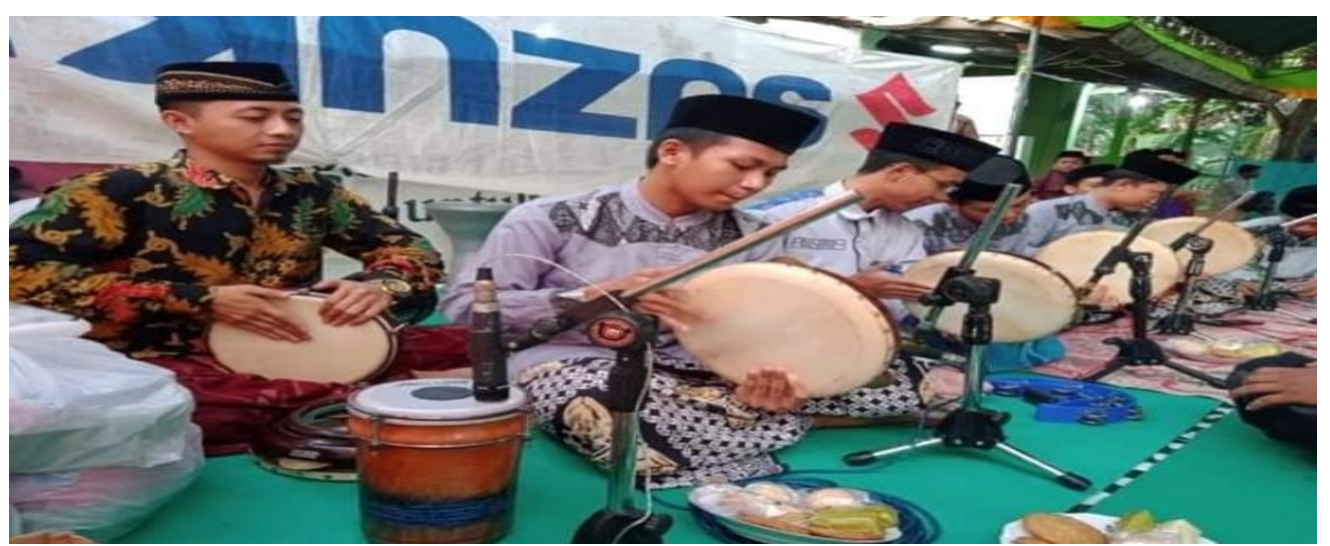

Gambar 5. Penampilan hadrah Banjari

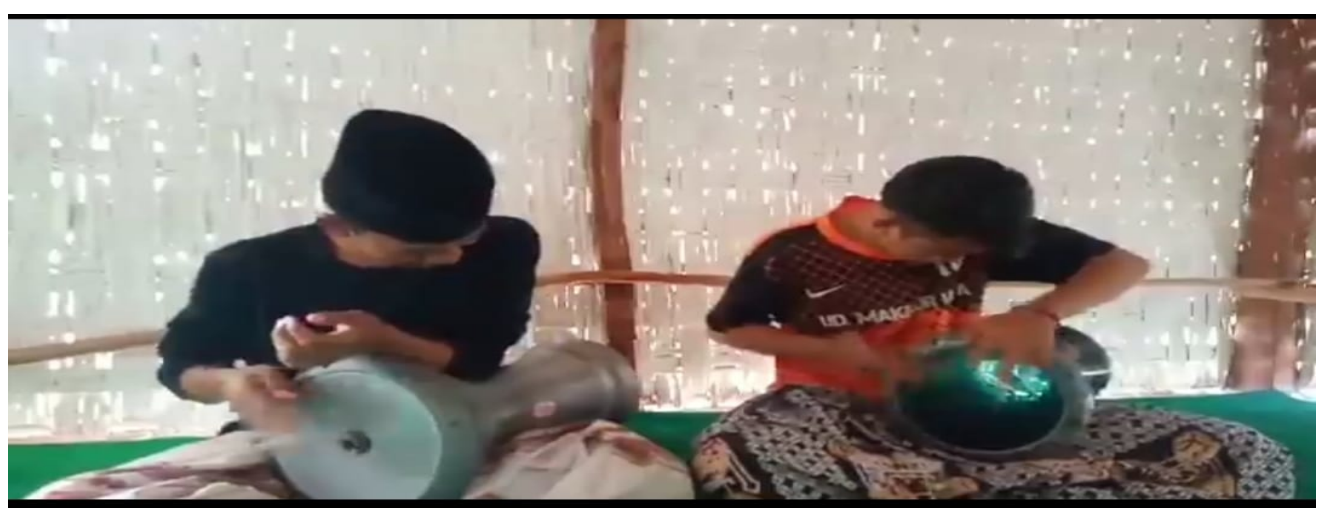

Gambar 6. Pelatihan dan Pendampingan Alat Darbuka

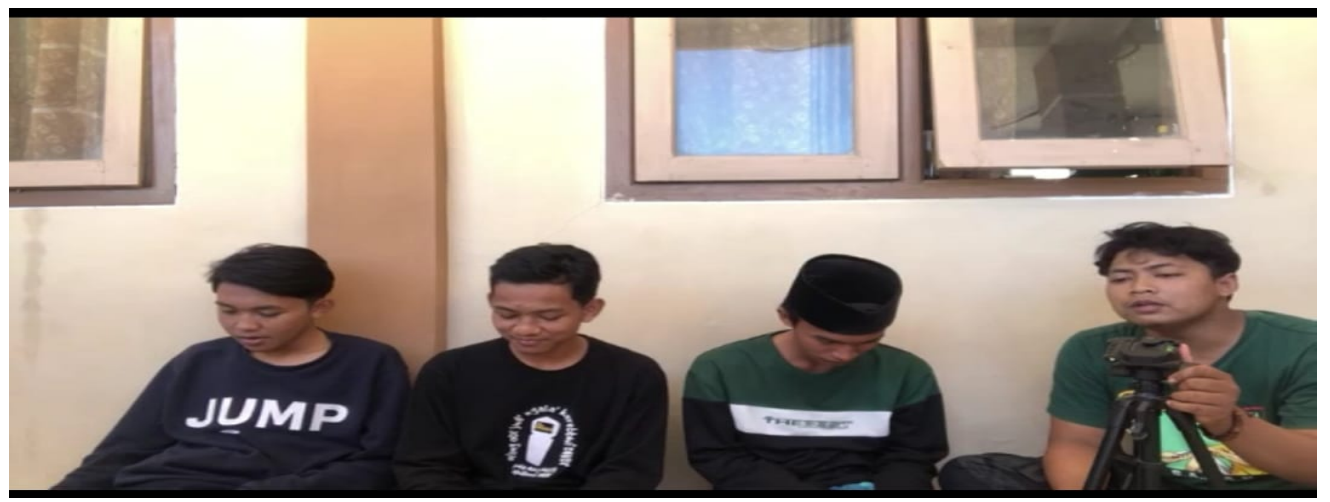

Gambar 7. Pelatihan dan Pendampingan Vokalis Sholawat

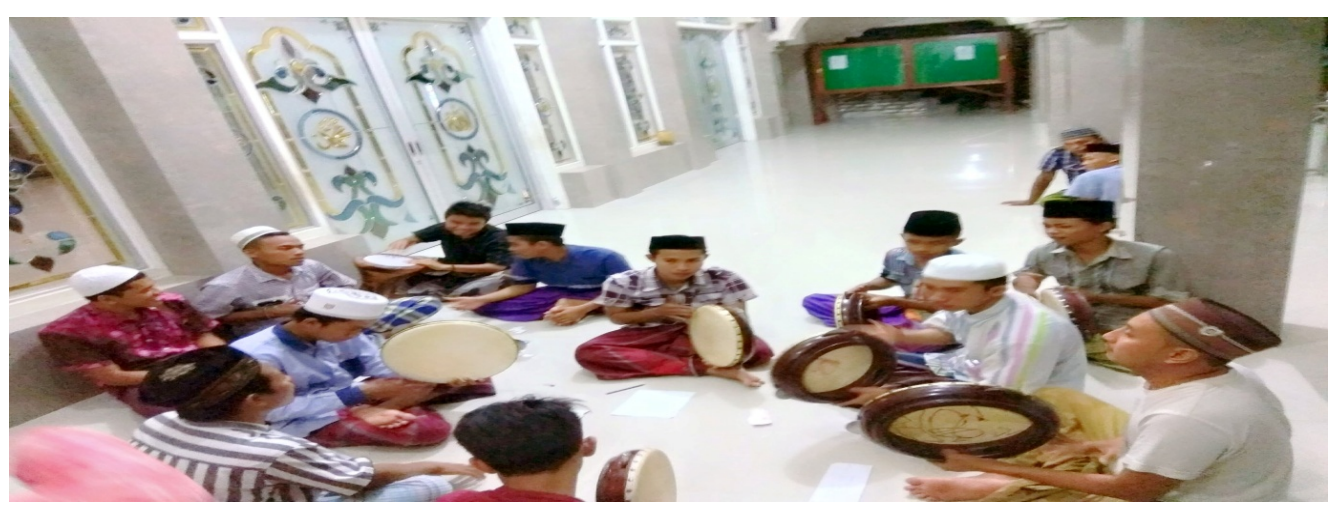

Gambar 8. Pelatihan dan Pendampingan alat Hadrah Banjari 


\section{Penutup Kegiatan Pengabdian}

Akhir dari kegiatan pengabdian ini, ditutup dengan pembacaan do'a oleh tokoh agama Desa Ponteh. Namun sebelum itu, tim pengabdian melakukan wawancara terhadap mitra, apa yang menjadi permasalahan dan bagaimana kelanjutannya bahwa hadrah banjari dari segi financial dapat membantu dana operasional masjid. Apakah remaja masjid akan mendirikan kelompok atau group baru hadrah banjari atau tidak? Mengingat harga alat-alatnya tergolong mahal. Ketiga ta'mir masjid menyatakan akan melihat kembali apakah remaja masjid masing-masing mempunyai minat atau skill dalam memainkan alat hadrah banjari. Kalau mereka minat, maka akan dimusyawarahkan di tingkat kepengurusan ta'mir masjid masing-masing.

\section{Faktor Penghambat dan Pendukung Pengabdian}

Dalam pelaksanaan kegiatan pengabdian masyarakat di Masjid Rabi'atul Adhawiyah, tim pengabdian menemukan beberapa faktor penghambat diantaranya adalah sebagai berikut:

1. Remaja masjid belum memahami secara baik dalam menyusun laporan keuangan masjid.

2. Remaja masjid kesulitan memainkan alat hadrah banjari karena tidak terbiasa, hal ini membutuhkan waktu yang banyak. Tidak cukup hanya pelatihan sekilas dengan waktu yang singkat.

3. Harga alat hadrah banjari yang mahal dan membutuhkan dana yang cukup besar mengingat dana operasional masjid diperoleh dari kotak amal jumat.

Faktor penghambat di atas, dapat diatasi dengan cara musyawarah yang dilakukan oleh setiap ta'mir masjid Desa Ponteh, selama remaja masjid mau belajar dan berkeinginan untuk membentuk group baru hadrah banjari. Dalam hal ini Kepala Desa dapat menjadi mediator dan fasilitator demi majunya desa dan menopang kesejahteraan remaja masjid khususnya memakmurmkan masjid. Oleh karena itu, salah satu faktor pendukung dari pengabdian ini adalah sebagai berikut:

1. Adanya dukungan moral dan material dari Kepala Desa Ponteh

2. Salah satu pelatih hadrah banjari adalah putra desa yang siap membantu jika memang ingin mendirikan groupbanjari

\section{Kesimpulan}

Hasil dari pengabdian masyarakat yang dilakukan antara lain:

1. Pengabdian kepada masyarakat tentang Pemberdayaan Manajemen Remaja Masjid dalam Meningkatkan Ekonomi melalui Hadrah Banjari di Desa Ponteh Kecamatan Galis Kabupaten Pamekasan berjalan dengan lancar dan kondusif. Hal ini terbukti dengan banyaknya peserta yang hadir, antusias dan menyimak setiap program kegiatan baik materi, pertunjukan dan pelatihan.

2. Penyampaian materi dalam seminar menggunakan pendekatan dengan teknik indoktrinasi dan teknik klarifikasi.

3. Remaja masjid memahami kajian tentang manajemen keuangan, meningkatkan ekonomi dan hadrah banjari. 
4. Alat hadrah banjari akan dimusyarahkan oleh ta'mir masjid dan Kepala Desa selama remaja masjid bersungguh-sungguh untuk belajar.

\section{Saran}

1. Tim pengabdian berharap, agar semua ta'mir masjid Desa Ponteh selalu semangat dalam memakmurkan masjid, baik dalam kegiatan hari besar keagamaan,

2. Ta'mir masjid dengan remaja masjid menjalin komunikasi yang baik dan selalu melakukan musyawah dalam memutuskan segala urusan yang berkenaan dengan masjid.

3. Menjaga manajemen masjid baik dalam keuangan, kegiatan dan tour ziarah sebagai wisata religi.

\section{Ucapan Terimakasih}

Tim pengabdian mengucapkan banyak terima kasih kepada mitra yakni Kepala Desa Ponteh sebagai penanggung jawab, ketiga masjid: masjid al-Falah, Rabi'atul Adhawiyah dan al-Falah, sehingga kegiatan pengabdian kepada masyarkat sebagai Tri Dharma Perguruan Tinggi Universitas Madura dapar berjalan dengan baik. Kepada pengelola JAI: Jurnal ABDIMAS Indonesia yang telah mempublikasikan pengabdian ini. Semoga pengabdian ini dapat memberikan kontribusi dan pemahaman baru untuk memajukan dan memakmurkan masjid di Indonesia.

\section{Referensi}

Al-Mubarakfuri SyaikhShafiyyurahman. (2008). Sirah Nabawiyah. Jakarta: Pustaka AlKautsar. 205.

Arif, Armai. (2002). Pengantar dan Metodologi Pendidikan Islam. Jakarta: Ciputat Press. $135-136$.

Madjid, Nurcholis. (2002). Masyarakat Religious Membumikan Nilai-nilai Islam dalam Kehidupan Masyarkat. Jakarta, Paramadina. 98-100.

Mudjahidin. (1985). Keindahan Karya Seni di Tinjau dari Beberapa Sudut Pandang Baik Al-Qur'an dan Hadis. Jakarta: PT. Gunung. 3.

Rozi, Mohammad Fahrur. (2017). 1'stAnnualConferenefor Muslim Scholar: Kopertais Wilayah IV Surabaya dalam Internalisasi Nilai-nilai Pendidikan Agama Islam dalam Memperkokoh Negara Kesatuan Republik Indonesia. Surabaya: Kopertais IV Surabaya Press. 935.

Siswanto. (2005). Panduan Praktis Organisasi Remaja Masjid. Jakarta: Pustaka Al-Kautsar. 23.

Tunggal, Amin Widjaja. (2002). Manajemen Suatu Pengantar. Jakarta: PT Rineka Cipta. 5. 